\title{
CERBERA ODOLLAM POISONING- ECG AND CARDIAC CHANGES
}

\author{
Sankaran Mohandas ${ }^{1}$
}

${ }^{1}$ Associate Professor, Department of Forensic Medicine, Sree Gokulam Medical College and Research Foundation, Venjaramoodu, Thiruvananthapuram, Kerala.

\section{BACKGROUND}

ABSTRACT

Cerbera odollam is a common vegetable suicidal agent in Kerala, where its incidence is next to the insecticidal group of poisons. The most important toxic principle acting on the cardiovascular system is cerberin. The toxins act on the cardiovascular system by two entirely different ways: 1) Haemorrhage in the conducting tissue of heart: SA node, AV node, AV bundle or bundle branches causing alterations in the impulse production and conduction and 2) Hyperkalaemia- ECG changes/ Dysrhythmias. The structural changes in the conducting tissue of heart and the electrolyte changes in the serum, either alone or in combination cause many ECG changes, precipitating a 'heart attack.' Suicidal Cerbera Odollam poisoning is seen only in South Kerala, nowhere else in the world. It is a cardiac poison producing 'Heart attack' and sudden death. Yet detailed studies- both ECG in clinical cases and Conducting Tissue of Heart in autopsy cases- are limited. Hence, the present study is undertaken.
\end{abstract}

\section{MATERIALS AND METHODS}

1. ECG changes recorded in 20 reliable cases of Cerbera odollam poisoning treated.

2. Histopathological changes in cardiac tissue in 20 reliable cases autopsied.

\section{RESULTS}

1. ECG changes, variable in nature, were noted in all the 20 cases.

2. Haemorrhage was noted in $80 \%$ of cases in the conducting tissue of the heart- SA node, AV node, AV bundle or bundle branches.

\section{CONCLUSION}

Cerbera odollam is a common suicidal agent confined to the Southern Kerala. Death is due to 'heart attack' precipitated by the ECG changes produced by hyperkalaemia or structural changes in the heart, either alone or in combination.

\section{KEYWORDS}

Cerbera Odollam Poisoning- ECG and Cardiac Changes.

HOW TO CITE THIS ARTICLE: Mohandas S. Cerbera odollam poisoning- ECG and cardiac changes. J. Evolution Med. Dent. Sci. 2018;7(01):111-115, DOI: $10.14260 /$ jemds/2018/24

\section{BACKGROUND}

Cerbera odollam (Suicide tree, Buddha tree, Sea mango, Jungle mango) is a poisonous shrub seen all over India. Botanical name is Cerbera odollam Gaertn. It is known as 'othalanga' or 'chatanga' in Malayalam. The fruit resembles mango and its kernel contains various toxic principles. It is the most common plant suicidal agent in the coastal belt of South Kerala in India. The powerful kernel is taken as suchafter grinding it with jaggery or after preparing a 'curry' with it. It is occasionally used as a perfect homicidal agent; the kernel may be added to toddy, liquor or food. $(1,2,3,4,5,6,7,8)$

'Financial or Other Competing Interest': None.

Submission 26-10-2017, Peer Review 11-11-2017,

Acceptance 19-12-2017, Published 01-01-2018.

Corresponding Author:

Dr. Sankaran Mohandas,

Sabarigiri,

LVMRA 31,

Kunnukuzhi,

Vanchiyur PO,

Thiruvananthapuram- 695035.

E-mail: mohandasdrs@gmail.com

DOI: $10.14260 /$ jemds $/ 2018 / 24$

\section{(c) (i) $\ominus$}

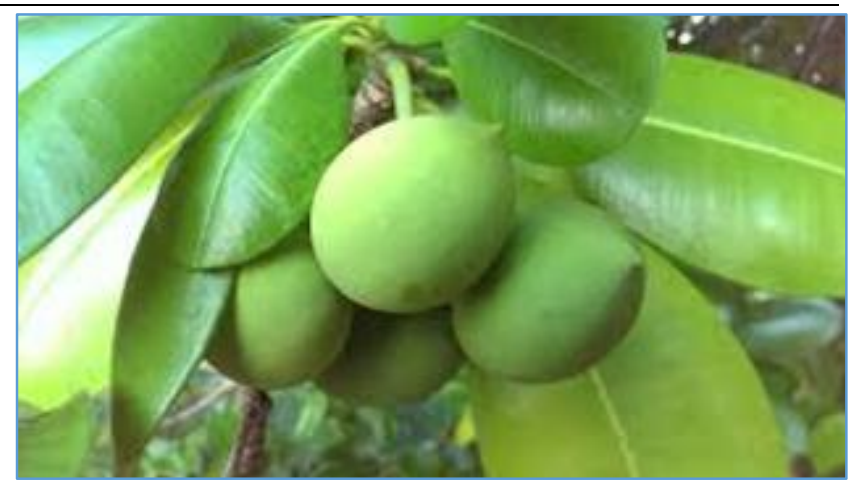

\section{Pharmacological Aspects}

Cerbera odollam is a cardiac poison. The toxic principles are cerberin, cerberoside, odollin, odollotoxin, thevetin, cerapain, 17-alpha neriifolin, 17-beta neriifolin, tanghinin and desacetyl tanghinin. Cerberin, the most powerful among the toxins, is a cardiac glycoside almost similar in toxicity to digitalis found in Foxglove. Toxic effects resemble those produced by digitalis. Cerberin has some advantages without the disadvantages of digitalis. Cerberin and Cerberoside produce negative chronotropic, negative bathmotropic and negative dromotropic effect on the heart. Ionotropic action varies with the dose, so is blood pressure. Both Odollin and Odollotoxin stimulate the intestinal musculature and act as cathartics. Kernel of one fruit is lethal for man. 
Page stated in 1964 that cardiac glycosides specifically inhibit the active transport of $\mathrm{Na}^{+}$out of the heart muscle cells resulting in a net cellular accumulation of $\mathrm{Na}$ and net cellular loss of K. Narendranathan et al gave a postulate in 1975 that the toxins lead to inhibition of membrane ATPase resulting in loss of intracellular $\mathrm{K}^{+}$and increase in extracellular $\mathrm{K}^{+}$. An increase in extracellular $\mathrm{K}^{+}$concentration causes a decrease in the ratio of diastolic depolarisation, so that the distance between two action potential is increased leading to bradyarrhythmias and slowing of conduction. This action is secondary to its depression on the Sodium pump as well as its parasympathetic action. $(1,9,10,11,12,13,14)$

\section{Gastrointestinal}

1. Direct irritation of stomach mucosa.

2. Parasympathetic.

\section{Central Nervous}

Depression of central synaptic transmission.

\section{Cardiovascular}

1. Through vagus nerve.

2. Direct depressant action on the myocardium.

3. Decreasing the slope of phase 4 of action potential by inducing hyperkalaemia.

4. Haemorrhage and structural changes in the conducting tissue. $(11,14)$

\section{Cytotoxic}

- Neriifolin and Desacetyl tanghinin have antiproliferative/ cytotoxic effect; tried in Oral Epidermoid $\mathrm{Ca}$, Small cell lung Ca, Breast Ca (anti-oestrogenic).

- Antioxidant.

\section{MATERIALS AND METHODS}

This is Case Series of 20 cases of Cerbera odollam poisoning having reliable history, treated in Medical College, Trivandrum and later autopsied there were included in this study. This group comprised of 10 males and 10 females aged between 16 and 38 years.

\section{Study Design}

A. This is Case Series of 20 adult conscious patients admitted with cent percent reliable history of consuming kernel(s) of Cerbera Odollam, admitted and treated in Medical College, Trivandrum, were included for studying the Serum Potassium and ECG changes. Serum Potassium level were assessed and ECG with long lead II were taken for all the cases at the time of admission. The group included 15 patients who could be saved and 5 patients who could not be saved. There were 10 males and 10 females among the cases chosen. Observational method was used.

B. Heart from 20 bodies who died due to consumption of kernels of Cerbera Odollam autopsied at Medical College were subjected to histopathological examination of the conducting tissue. The group included 5 cases who were clinically followed and 15 cases who were not clinically followed. There were 10 males and 10 females. All these 20 cases were later tested positive for toxins of Cerbera Odollam.

\section{RESULTS}

The author has studied the ECG changes and conducting tissue of heart in 20 cases of Cerbera odollam poisoning. Histopathological changes: Haemorrhage was noted in $80 \%$ of cases in the conducting tissue of the heart: SA node, AV node, AV bundle or bundle branches. Any structural change in the SA node, AV node or the peripheral parts of the conducting tissue is likely to cause alterations in the impulse production and conduction. Haemorrhage was detected in those areas of heart having abundant vascular supply.

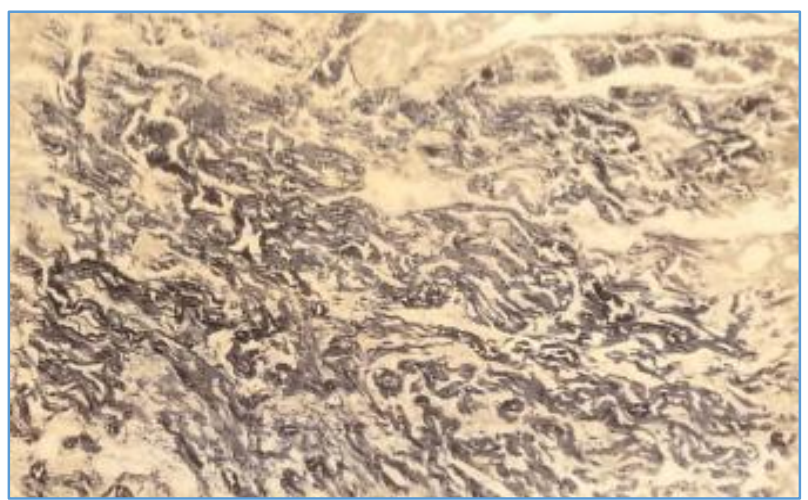

SA Node showing Congestion and Haemorrhage H and E $100 X$

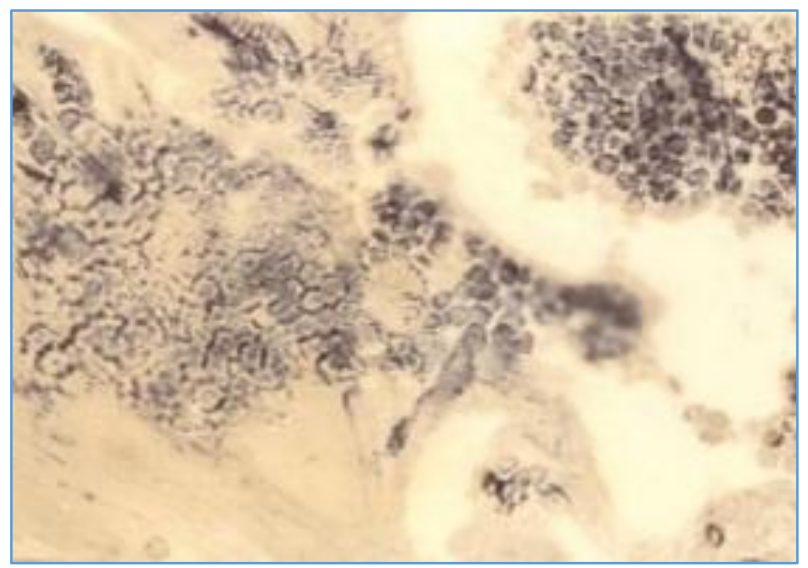

SA Node showing Haemorrhage H and E $1000 X$

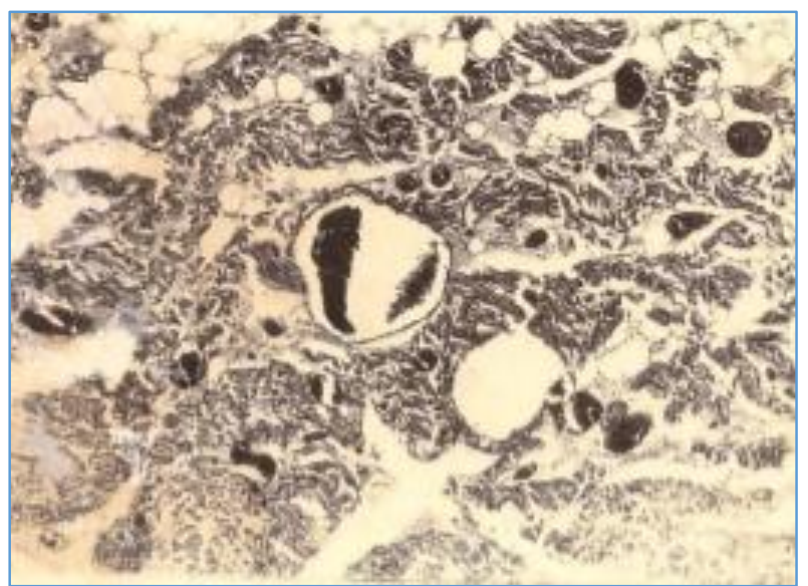

AV Node showing Congestion H and $\mathrm{E} 100 \mathrm{X}$ 


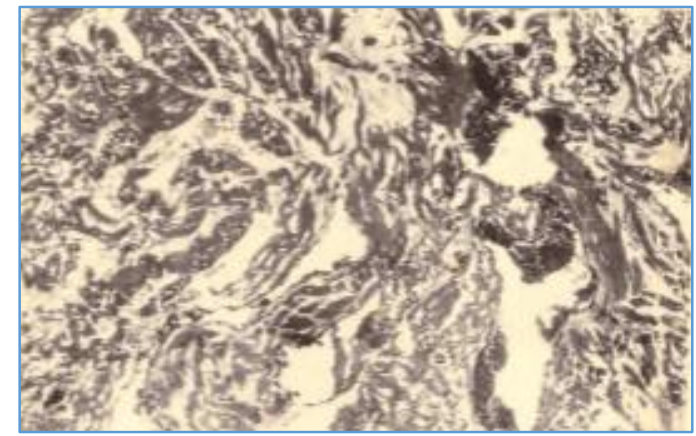

AV Node showing Haemorrhage H and E 100X

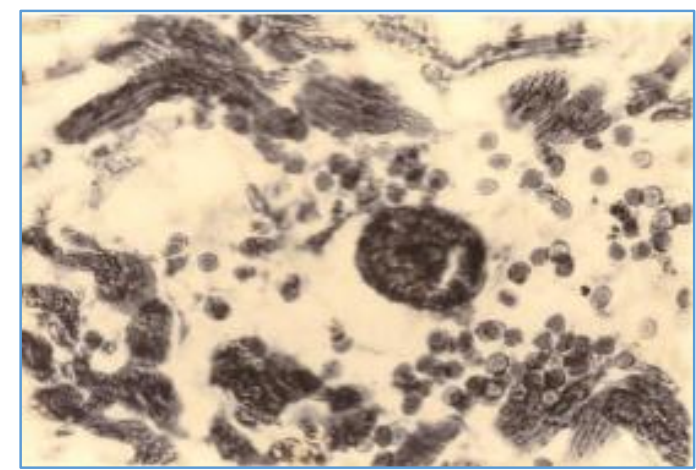

AV Node showing Haemorrhage H and E 1000X

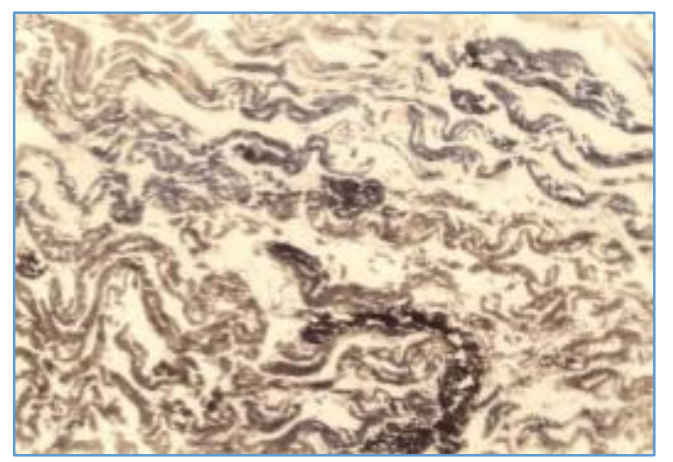

Atrial Muscle showing Haemorrhage H and E 100X

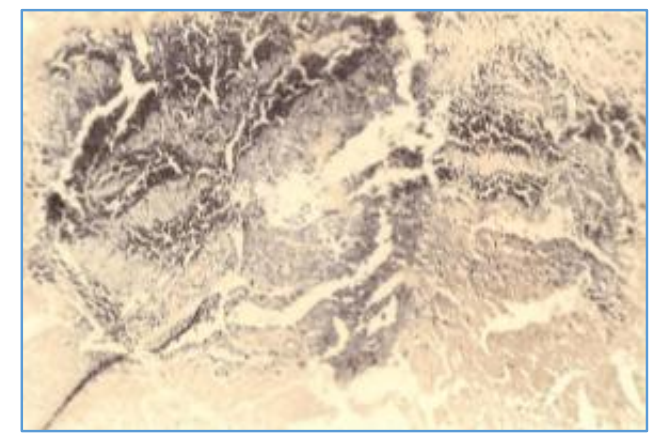

Ventricular Muscle showing Haemorrhage H and E 100X

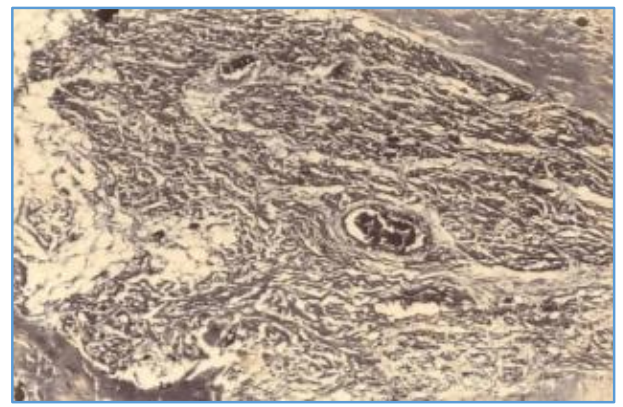

AV Bundle showing Congestion and Haemorrhage $H$ and $E$ 100X

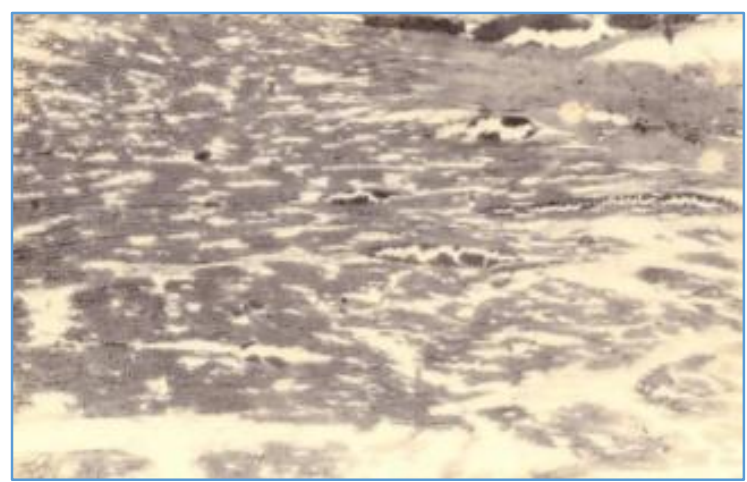

\section{Bundle Branch showing Congestion and} Haemorrhage H and $\mathrm{E} 100 \mathrm{X}$

ECG Changes were noted in all the 20 Cases

1. Normal sinus rhythm.

2. Sinus bradycardia.

3. Sinus bradycardia with junctional escape.

4. Wandering pacemaker.

5. Junctional rhythm.

6. Atrial fibrillation.

7. SA block.

8. SA block + AV block.

9. AV block: $1^{\text {st }}$ degree, $2^{\text {nd }}$ degree, complete heart block.

10. Ventricular extrasystole.

11. ST changes: ST sagging, ST depression, ST depression with depression of J point.

12. T-wave changes: Flat $\mathrm{T}$-waves, Biphasic $\mathrm{T}$-waves, Inverted $\mathrm{T}$-waves, Tall tented T-waves.

13. Prominent $U$-waves.

14. Shortening of QT interval.

ECG changes were reported even after two years. They could be permanent and could be due to the structural changes produced in the conducting tissue due to haemorrhage.

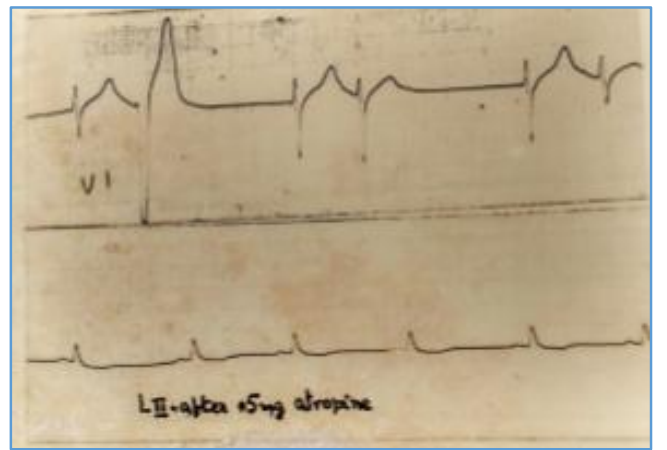

Top: Ventricular Extrasystole. Bottom: Disappeared with Inj. Atropine

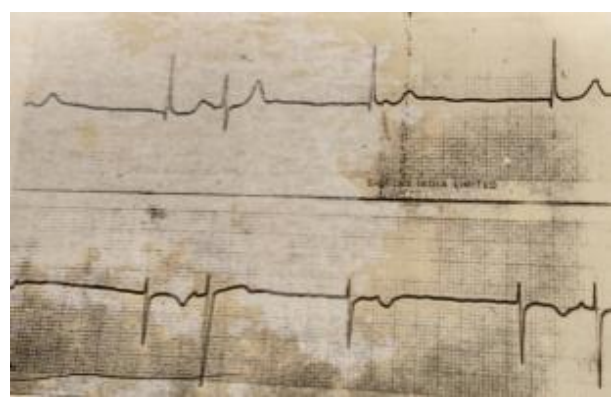

AV Dissociation 


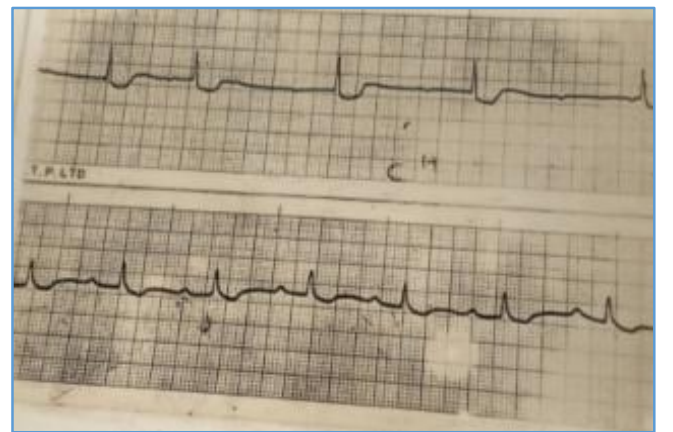

Complete Heart Block with Irregular Ventricular Rhythm
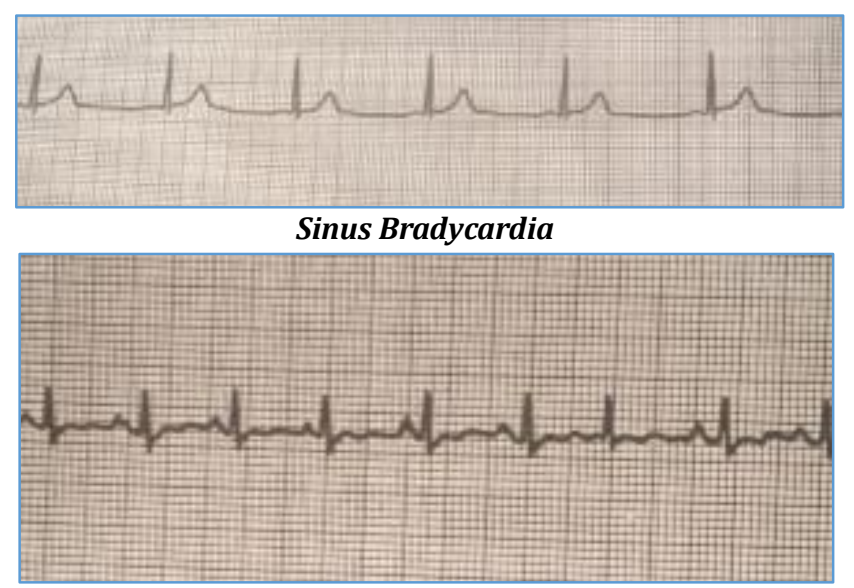

Wandering Pacemaker

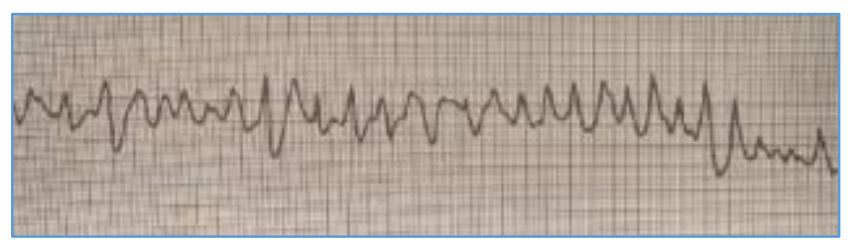

Ventricular Fibrillation

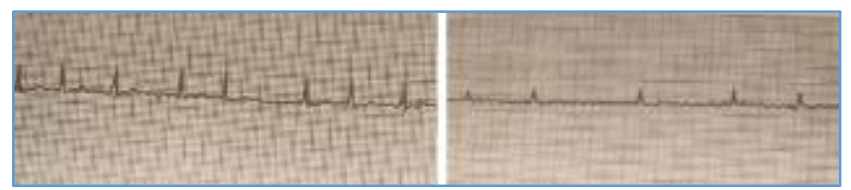

Atrial Fibrillation

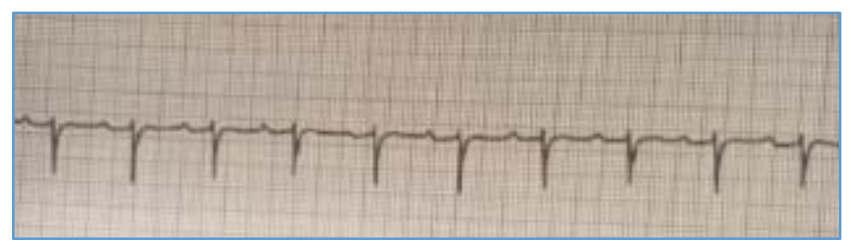

Incomplete AV Block - First Degree

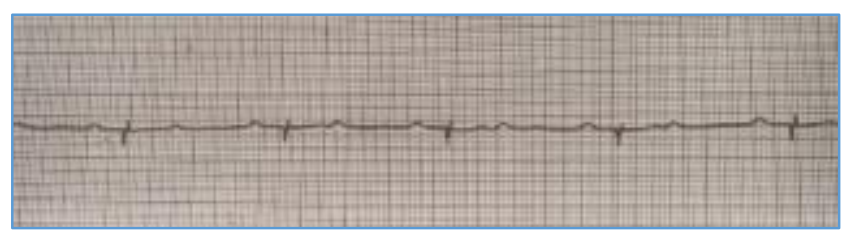

Incomplete AV Block - Second Degree

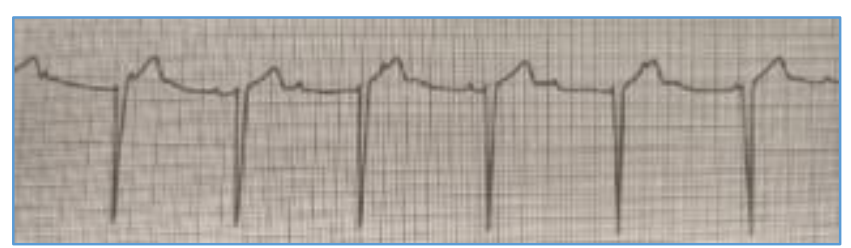

Complete AV Block - Third Degree

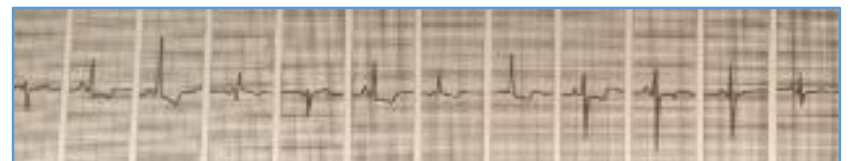

Incomplete Right Bundle Branch Block

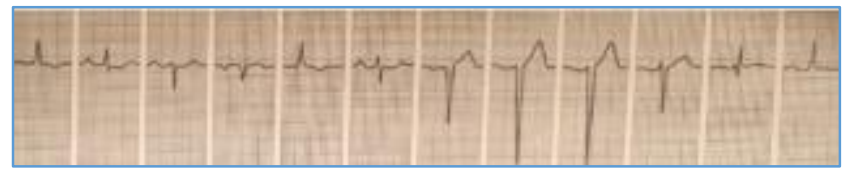

Incomplete Left Bundle Branch Block

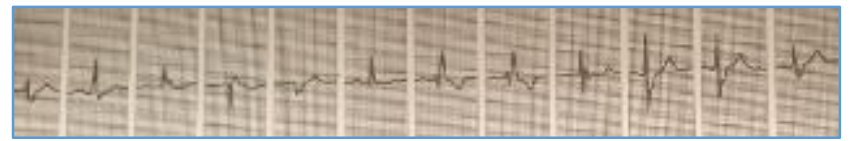

Complete Right Bundle Branch Block

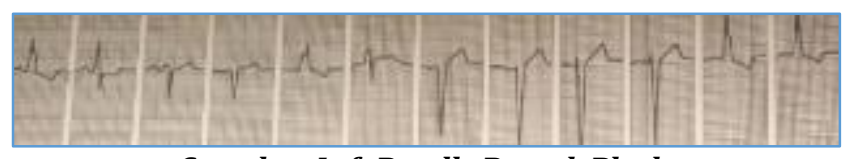

Complete Left Bundle Branch Block

Hyperkalaemia was noted in all the 20 cases.

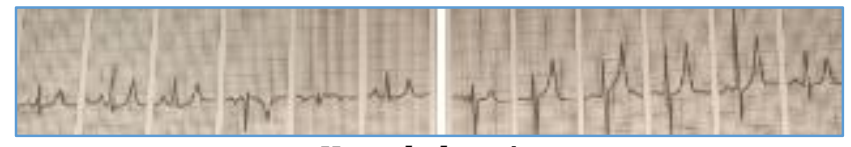

Hyperkalaemia

\section{DISCUSSION}

Cerbera odollam is a poisonous plant present in the southern coastal parts of Kerala. The kernel of the fruit contains cardiac toxins like Cerberin, Cerberoside; intestinal irritants like Odollin, Odollotoxin and cytotoxic molecules. It is a common suicidal agent in Kerala with $25 \%$ mortality rate. Its incidence is next to the insecticidal poisoning. It comprises $50 \%$ of the plant poisoning cases. Death is due to 'heart attack' produced by the poison. It can be a perfect murder weapon like Ricin and Abrin, especially outside Kerala where it is least suspected and the identification is difficult unless sophisticated tests are routinely employed.

\section{CONCLUSION}

Cerbera odollam is the most common plant with suicidal agent in the coastal areas of Southern Kerala in India, moreso among the females. It can be a perfect murder weapon especially in places outside Kerala; death is due to 'heart attack' caused/ precipitated by the poison by the structural changes in the conducting tissue of heart and the hyperkalaemia produced in the serum either alone or in combination.

\section{REFERENCES}

[1] Bourdillion TF. Forest trees of Travancore. The Travancore Government Press 1908: p. 233.

[2] Chopra RN, Nayar SL, Chopra IC. Glossary of Indian medicinal plants. New Delhi: Council of Scientific \& Industrial Research 1956.

[3] Chopra RN, Bose BS, Gupta JC, et al. A preliminary study of the pharmacological action of the glycoside of cerbera odollam. Indian J Med Res 1942: p. 30 \& 107. 
[4] Kirtikar KR and Basu MD. Indian medicinal plants. Vol. 3. $2^{\text {nd }}$ edn. Dehra Dun: International Book Distributors 1987:1552-3.

[5] Ferris JAJ. Hypoxic Changes in conducting tissue of the heart in sudden death in infancy syndrome. Br Med J 1973;2(5857):23-5.

[6] Iyer GV, Narendranath M. A preliminary report on the neurological manifestations of Cerbera odollam poisoning. Indian J Med Res 1975;63(2):312-4.

[7] Kini PM, Pai KN. Cardiotoxic effects of Cerbera odollam. Indian Heart J 1965;17(3):263-70.

[8] Kunhali K, Pillai MV, Das KV. Poisoning with Cerbera odollam. Indian Heart J 1970;22:373.

[9] Narendranathan M. Thesis submitted to the Kerala University. 1974.
[10] Rangaswami S, Rao VE. Active principles of Cerbera odollam Gaertn. J Scientific and Industrial Research 1957;16B:209.

[11] Vijayaraghavan G, Kuruvila A, Warrier NS, et al. Cardio vascular effects of Cerberin. India Heart J 1974;26:74.

[12] Page E. The actions of cardiac glycosides on heart muscle cells. Circulation 1964;30(2):237-51.

[13] Narendranathan M, Das KV, Vijayaraghavan G. Electro cardio graphic changes in Cerbera odollam poisoning. J Assoc Physicians India 1975;23(11):757-62.

[14] Stock JP. New frontiers in arrhythmias. Br Heart J 1971;33(6):809-16. 